\title{
"SÓ POR FORMALIDADE": A INTERACÃO ENTRE OS SABERES ANTROPOLÓGICO, JURIDICO E JUDICIAL EM UM "JUICIO PENAL"
}

\section{Lucía Eilbaum \\ Universidade Federal Fluminense - Brasil}

Resumo: Neste artigo proponho-me a refletir sobre minha participação em um "juicio" contra seis policiais, acontecido na cidade de La Plata, na Argentina. A partir do meu envolvimento como "testigo" e do acompanhamento da audiência, identifico a confluência de três saberes distintos: o antropológico, o jurídico e o judicial. A partir dessa distinção, proponho pensar a relação entre fatos e leis como própria de diferentes saberes e, portanto, tendo diferentes graus de legitimidade e de verossimilhança no âmbito dos tribunais. Meu objetivo é mostrar que, no "juicio" do qual participei, o saber antropológico, o jurídico e o judicial apresentaram sensibilidades jurídicas, relativas às posições e interesses defendidos e aos fazeres especificos que eles representam.

Palavras-chave: antropologia, etnografia, judicial, jurídico.

Abstract: In this article, my proposal is to reflect about my participation in a judgment against six policemen, which had happened in La Plata city in Argentina. From the point of view of my engagement as a "witness" and from the observation of the session, I had identified the confluence of three kinds of knowledge: the anthropological, the juridical and the judicial. From that distinction, it will be suggested to think about the relation between facts and law as being specific from different types of knowledge, and furthermore having different levels of legitimacy and likelihood in the judicial context. My goal is to demonstrate that, in that judgment, the anthropological, the judicial and the juridical knowledge present legal sensibilities related to the positions and interests being defended, and to the specifics actions that they represent.

Keywords: anthropology, ethnography, judicial, juridical. 


\section{Introduç̃o}

No dia 19 de abril de 2010, começou na localidade La Plata, capital da província de Buenos Aires, o julgamento contra seis policiais da polícia dessa província. Havia muitos anos que eu acompanhava com interesse acadêmico audiências de juicio. ${ }^{1}$ Mas o julgamento daquele abril correspondia a uma situação completamente inédita para mim. Estava sendo proposta, por uma das partes do processo, para depor na qualidade de antropóloga. Seria a primeira vez que participaria de um julgamento fora do lugar de observadora e teria uma intervenção como depoente.

Neste trabalho proponho-me a refletir sobre minha participação no julgamento e sobre o acompanhamento da audiência no sentido de identificar a confluência de três saberes distintos: o antropológico, o jurídico e o judicial. A partir dessa distinção, no final do artigo, proponho um diálogo com o conhecido trabalho de Clifford Geertz (2002a) O saber local: fatos e leis em uma perspectiva comparada, no sentido de pensar a relação entre fatos e leis como própria de diferentes saberes e, portanto, tendo diferentes graus de legitimidade e de verossimilhança no âmbito dos tribunais. Meu objetivo é mostrar que, naquele juicio, o saber antropológico, o jurídico e o judicial apresentaram diferentes "sensibilidades jurídicas", relativas às posições e interesses defendidos e aos fazeres específicos que eles representam.

Eu tinha tomado conhecimento do caso, em abril de 2009, em entrevista com um advogado criminal. Luis Real era um advogado de aparência juvenil e informal. Na sua apresentação, Luis marcava uma posição que o afastava do papel de um advogado tradicional - cujo objetivo e interesse fossem defender o cliente através de estratégias jurídicas e judiciais de intervenção - e também de um perfil de advogados vinculados à defesa de casos paradigmáticos de violações aos direitos humanos. Luis ressaltava um perfil que, durante o "juicio", se mostraria também fora do padrão esperado no ambiente judicial.

No decorrer de nossa entrevista, tomei conhecimento pela primeira vez do "caso de Dario", como Luis o identificava. Ele era o advogado representante da família do jovem. Meus sucessivos encontros com Luis estiveram marcados pela troca de opiniões sobre o caso e também sobre minhas pesquisas e

1 As categorias nativas aparecem entre aspas e as categorias em espanhol, em itálico.

Horizontes Antropológicos, Porto Alegre, ano 18, n. 38, p. 313-339, jul./dez. 2012 
atividades como antropóloga. A partir de nossas conversas, foi tomando forma a proposta de Luis Real para eu depor no julgamento.

\section{0 caso}

O processo em questão envolvia um caso que, na Argentina, poderia ser classificado sob a categoria de "violência policial". Resapo, um dos policiais julgados, estava sendo acusado pelo crime de "homicídio agravado". Os outros cinco policiais, por "encobrimento agravado". Em todos os casos, a figura penal "agravado" fazia referência a um endurecimento da acusação em função de se tratar de crimes supostamente cometidos por funcionários públicos - policiais - em exercício de suas respectivas funções.

O "fato" julgado tinha origem em um dia de janeiro de 2007, quando Resapo tinha intervindo na apreensão de Dario, um jovem de 17 anos, que, junto com um amigo, teria ingressado na casa de um policial e roubado alguns pertences. Foi na viatura policial que conduzia Dario para a sede policial que um tiro da arma de Resapo o atingiu na cabeça. A reconstrução dos fatos indicou que Resapo estava pressionando - "apretando" no jargão policial - Dario para que falasse - confessasse - onde se encontrava o amigo dele, o qual teria fugido em outra direção. Com esse objetivo na mira, Resapo posicionou a sua arma na têmpora de Dario. Este afirmava que não conhecia o outro menino e Resapo insistia... Foi quando Sánchez, o motorista da viatura, escutou um disparo, que atingiu Dario. Diante dessa situação, os dois policiais se comunicaram com seu superior hierárquico, Gómez. No trajeto ao hospital, começou a se configurar uma trama de produção de provas que, posteriormente, acabaria levando Sánchez, Gómez, o comisario, o subcomisario e um oficial de serviço ao banco dos réus.

Aquela trama evidenciou formas de investigação e produção de provas observáveis em outras intervenções policiais e, sobretudo, em rotinas e práticas próprias da instituição policial. Cada uma delas identificável com categorias nativas específicas, cuja análise evidencia a naturalização de tais práticas na socialização policial. ${ }^{2}$ Expor parte dessas questões era o objetivo do advogado Luis Real, ao me propor depor como "antropóloga especialista" durante

2 Para uma análise do caso em relação a essas práticas, ver Eilbaum (2011) e Gubilei (2009). 
o julgamento. "Temos que demonstrar - me dizia - que Resapo não é um maluquinho que atirou, mas que está coberto e encoberto por formas típicas de intervenção policial."

Segundo a argumentação de Luis Real durante o juicio, a cadeia de cumplicidade e encobrimento era maior do que aqueles seis policiais. "Podem ser mais dos que estão, mas destes que aí estão não sobra nenhum", afirmou várias vezes durante as audiências. Sobre o fazer policial envolvido naquela "trama de cumplicidade" trataria meu depoimento. Dessa forma, o caso tinha a potencialidade de envolver não só o julgamento dos imputados individualmente, mas de certas práticas institucionais. Esse era meu papel, segundo solicitado por Luis.

Cheguei a Buenos Aires em um sábado. No domingo, um dia anterior ao início do juicio, me reuni com Luis. Naquela reunião, ele ressaltou que não era para eu falar sobre "os fatos" do processo, mas para contar minha experiência e trabalho na pesquisa sobre práticas e rotinas policiais, em especial nos chamados casos de "violência policial". Ele dizia que seu objetivo era justamente ressaltar uma sistematicidade no fazer policial. A experiência de depor, no dia seguinte, me depararia com outro tipo de expectativa por parte do tribunal.

\section{Do outro lado do juicio}

A audiência estava marcada para começar às nove horas, nos tribunais penais, na cidade de La Plata. Eu estava escalada para depor no último dia do juicio. Essa previsão implicava que eu, como testemunha, não poderia assistir à audiência antes de depor. Assim, Luis Real solicitou ao Tribunal que pudesse depor no primeiro dia. Após meu depoimento, eu poderia assistir às demais sessões. Pelas dúvidas, fui acompanhada de meu marido, também antropólogo, que se comprometeu a tomar notas sobre o desenvolvimento do juicio enquanto eu esperava do outro lado. Em princípio, parecia que não haveria problema com a mudança de dia, mas isso seria confirmado posterior e formalmente na sala de audiência, pois todas as "partes" deviam dar seu consentimento.

Apresentamo-nos na "mesa de entradas" do "tribunal oral criminal" correspondente. Eu apresentei minha carteira de identidade, esclarecendo que vinha como testemunha. Já naquela hora senti que meu lugar não estava bem definido. Como testemunha daquele dia, eu devia aparecer na lista de nomes 
que a funcionária do tribunal segurava na mão. Mas meu nome não estava. Como testemunha, também não podia esperar junto com o público. Devia fazê-lo junto com as outras testemunhas, mas sem saber ainda se seria chamada para aquele dia.

Após esperar uma hora e meia, as pessoas que aguardavam para ingressar no térreo do prédio começaram a ser chamadas pelos policiais de custódia. Foi advertido para mim que fosse ao tribunal e me apresentasse novamente, pois "não podia estar com o público". Fiz isso, mas me foi indicado para descer novamente ao térreo, onde estava a sala de audiência. Um outro grupo de pessoas esperava em uma antessala. Eram as outras testemunhas daquele dia. Um policial, com uma lista na mão, chamava pelo nome e sobrenome a cada uma das pessoas que aguardavam. Fui reconhecendo o nome de muitas delas por tê-lo visto escrito no processo judicial. Eu fui a última a ser chamada. Fui revistada por uma policial, por sobre minhas roupas. Entrei em uma sala onde todas as outras pessoas já estavam sentadas em precários assentos. Era a sala onde as testemunhas aguardavam para ser chamadas.

Éramos 17 pessoas. Com exceção de mim e de outras quatro pessoas, todos eram policiais. Muitos deles conhecidos entre si. Cumprimentavam-se e conversavam sobre os novos "destinos", outros julgamentos e também, em um tom baixo de voz, sobre o caso em questão. Na sala havia um cartaz indicando a proibição do uso de celular, mas a maioria dos policiais falava ou enviava mensagens desde seus aparelhos.

Durante a espera sentia haver olhares dirigidos a mim, por parte de alguns policiais, possivelmente se perguntando sobre quem eu era. Eu era a única dos presentes naquela sala que não tinha deposto durante a etapa de investigação, três anos atrás. ${ }^{3}$ Também por isso era a única pessoa daquela sala que não podia ser encaixada em nenhum papel em torno dos fatos acontecidos; em uma palavra, não tinha testemunhado nada. Como ninguém me perguntava nada, também não disse nada. Até o final da espera, quando apenas restavam eu e dois policiais, aquele mais insistente no seu olhar acabou me perguntando. Respondi que tinha sido solicitada como "especialista" pelo advogado da família. "Ah", disse.

3 O processo penal argentino está dividido em duas etapas. A primeira destinada à investigação dos crimes e a segunda, ao seu julgamento.

Horizontes Antropológicos, Porto Alegre, ano 18, n. 38, p. 313-339, jul./dez. 2012 
Após alguns minutos de termos ingressado na sala, um funcionário do tribunal entrou com o Código Penal na mão. Explicou que seríamos chamados pelo sobrenome para depor. Disse que achava que, à exceção de uma pessoa (eu), todos já tinham deposto na etapa prévia. Então, da mesma forma que daquela vez, devíamos fazê-lo sob juramento de dizer a verdade. Por isso, leu para nós o artigo do código que castiga o delito de "falso testemunho" com penas de até quatro anos de prisão. Posteriormente, na sala de audiências, cada uma das testemunhas seria recebida com a pergunta do presidente do tribunal sobre se "jura ou promete dizer a verdade de tudo quanto lhe fora perguntado".

Soube que a audiência iria começar quando dois homens e uma mulher, todos formalmente vestidos - os homens de terno e gravata a mulher com terninho ${ }^{4}-$, de diversas idades, mas todos com mais de 50 anos, passaram através da sala de testemunhas. Eram os três juízes que comporiam o "tribunal oral". Um deles cumprimentou amigavelmente um dos policiais que estava como testemunha e, logo em seguida, continuou em direção à sala de audiências. Um funcionário do tribunal perguntou se queríamos água, mas todos dissemos que não. Não sabíamos ainda a longa espera que nos aguardava pela frente, sem novo oferecimento.

Uma hora depois de iniciado o julgamento, foi chamada a primeira testemunha, o oficial Talarico, o policial de quem Dario e seu amigo teriam roubado os pertences. Por ter assistido a muitos outros juicios orales, sabia que aquela primeira hora teria correspondido à exposição de cada uma das partes das linhas de acusação ou de defesa que manteriam ao longo do julgamento. Como além do promotor, de parte da acusação também havia o assistente da acusação, e como os acusados eram seis, não me surpreendeu a demora no chamado da primeira testemunha. Além das argumentações das "partes", cada acusado passava por um interrogatório de identificação, quando o presidente do tribunal perguntava os dados pessoais de cada um deles. A demora que me surpreendeu foram as duas horas e meia que duraria o depoimento de Talarico.

Nesse período, eu assistia como o ambiente da sala de testemunhas começava a se alterar em um tom de impaciência e perspectiva de longa espera. A maioria dos presentes teve seu momento de cochilo, à exceção de um que dormia provocando com seus fortes roncos comentários e risadas de todos

4 Nenhum funcionário judicial na Argentina usa toga. 
nós. A atitude dos quatros civis era diferente da dos policiais. Enquanto alguns dentre estes não emitiam reclamação nem se movimentavam de suas cadeiras, outros, que ocupavam cargos de maior hierarquia na instituição, conversavam entre eles, fumavam na janela e comentavam casos anteriores nos quais tinham esperado até as quatro da manhã para serem chamados. Um comentário não muito alentador para aqueles que, como eu, passavam pela primeira experiência de testemunhar. De qualquer forma, todos pareciam resignados, pois ao final de contas em lugar de estar "no serviço", naquele dia sua obrigação institucional era estar naquela sala.

As testemunhas civis eram duas duplas conhecidas entre si. A primeira constituída de uma senhora de aproximadamente 45 anos e um senhor de mais de 65; a segunda, por um jovem de no máximo 30 anos e um senhor de aproximadamente 55. No início da espera essas pessoas permaneceram quietas, sem conversar entre elas, nem se movimentar de suas cadeiras. Passado mais tempo, começaram a se soltar mais, emitindo comentários sobre a situação. A fome, o calor, estar no tribunal desde as $8 \mathrm{~h}$ da manhã, o longo caminho à casa que os esperava. O senhor que aparentava 55 anos comentou com seu par, com um olhar estendido para a sala toda: "Isto não tem lógica, chamar primeiro a quem mais tem para dizer! Deveriam nos chamar primeiro a nós que não temos muito para falar, 'a ver o que este mané tem para dizer...' e nos liberar logo, mas não, demoram duas horas e meia com o primeiro! Este país não tem lógica." A partir daquela pequena e circunscrita sala, era possível, como em muitos contextos da sociedade argentina, partindo de uma situação pontual, ouvir opiniões e comentários sobre o país, a política nacional e/ou a economia mundial. Esses saltos não excluíam opiniões sobre a Justiça, seu funcionamento e suas "eventuais" relações políticas.

No que a mim respeita, sentia que minha situação era diferente daquela dos policiais e dos civis. De alguma forma, eu sentia que eles reclamavam da espera e da "lógica" do procedimento e tinham "direito" a essa reclamação por estarem obrigados a estar presentes, sendo que tinham sido convocados judicialmente. Eu não tinha convocação alguma, "apenas" tinha sido proposta por uma das "partes", sem um papel muito definido e, inclusive, sem saber ainda se me seria permitido depor nesse dia. Minha participação parecia um compromisso com interesses acadêmicos e talvez políticos, mais do que uma obrigação cívica. A curiosidade etnográfica de saber e conhecer como era "o outro lado" de um "juicio" justificava para mim a espera e, ao mesmo tempo, marcava mais

Horizontes Antropológicos, Porto Alegre, ano 18, n. 38, p. 313-339, jul./dez. 2012 
uma diferença entre minha presença e a do resto das testemunhas. Fazia parte do meu "fazer antropológico" passar por situações como essas.

O tempo foi passando, lentamente. A segunda testemunha foi chamada para depor e começaram as especulações na sala sobre quem seria o próximo. O certo é que houve um momento em que as coisas começaram a se acelerar... Uma funcionária do tribunal ingressou na sala e chamou a testemunha seguinte. Passados menos de dez minutos, ela entrou de novo e chamou mais uma. Logo em seguida, voltou a ingressar com três carteiras de identidade na mão. Chamou as pessoas pelo nome e anunciou que podiam se retirar: "Foram desistidos. Muito obrigada e tenham um bom dia." Passados poucos minutos, o procedimento se repetiu novamente: a funcionária entrava e com um gesto de "simbora" ("vamos embora") apressava a quem tinha que depor e anunciava as novas "desistências". A "desistência" de uma testemunha se dava quando, com o acordo de todas as partes, se definia prescindir daquele depoimento. Foram "desistidos" três policiais e dois civis. O senhor que fez aquele comentário sobre a "lógica do país" foi "desistido". Fiquei pensando se sentiria uma sensação de alívio por ir embora ou se a decisão do tribunal reforçaria a sensação de "falta de lógica" e de um dia perdido. Às 4 h30 da tarde ficamos apenas duas pessoas na sala, eu e um outro policial. Este último, finalmente, também foi indicado para ir embora. A impaciência parecia não só haver tomado conta das testemunhas, mas também dos participantes da audiência, do outro lado da sala. De qualquer forma, a percepção do tempo transcorrido "do outro lado" me fez pensar no juicio como tendo um tempo próprio, que, para quem não estivesse assistindo ao rito - estivesse "do outro lado" - podia ser incompreendido, ou, pelo menos, percebido de forma diferenciada. Quero dizer, aquilo que, de um lado, era percebido como uma longa espera "sem lógica", do outro poderia corresponder ao ritmo que o ritual judiciário impõe a seu desenvolvimento. ${ }^{5}$

\footnotetext{
Antoine Garapon (1999, p. 53) enfatiza que o tempo do processo não é um tempo ordinário, mas que está composto por sinais, ritos e prescrições processuais que marcam - separam e unem - a qualidade do tempo. Segundo ele, a ordem do ritual judiciário indica que "cada um em seu lugar e cada coisa a seu tempo" (Garapon, 1999, p. 62), impondo uma cronologia e ritmo próprios deles. Ele aponta também o fato desse tempo ser "mais longo para o acusado do que para os profissionais do direito" (Garapon, 1999, p. 62), podendo estender essa percepção talvez para o público e para as testemunhas. Em um sentido semelhante, utilizando a conceitualização de Evans-Pritchard sobre a noção de tempo entre os nuer, Sofia Tiscornia (2006, p. 134-143) analisa o "tempo judicial", como um tempo não abstrato ou linear, mas relativo ao espaço social e às hierarquias sociais que organizam cada acontecimento em litígio. Embora
}

Horizontes Antropológicos, Porto Alegre, ano 18, n. 38, p. 313-339, jul./dez. 2012 


\section{"Eilbaum, Lucía"}

Finalmente, fui chamada para depor. A tranquilidade que as horas de espera tinham me proporcionado rapidamente se transformou em batidas aceleradas do coração. Ingressei à sala pela porta localizada no fundo da mesma, por onde ingressava também o "público". A visão desse ponto de ingresso foi, sucessivamente, uma fila em pé de policiais com uniforme e um tapete vermelho pelo qual eu teria que andar até subir a um estrado onde me aguardava uma cadeira com um microfone acoplado à sua frente. Diante do microfone, o balcão dos três juízes que integravam o tribunal e a secretária. Sabia que, à minha esquerda, estava Luis Real e o promotor, mas só olhei para eles quando, posteriormente, Luis se dirigiu a mim. Também sabia que, à minha direita, estavam os advogados defensores e, atrás deles, os seis acusados. Mas pouco olhei para eles naquele momento. A sala era muito mais formal do que outras que já conhecia. A presença do tapete vermelho, do estrado, do escudo da Justiça e da província de Buenos Aires, de uma cortina, espécie de telão, atrás do tribunal, constituía um diferencial em relação a outras salas.

Foi indicado onde me sentar. Quando o fiz, Luis Real encontrava-se em meio de uma conversa com o presidente do tribunal. Logo percebi que era sobre mim, ou melhor, sobre meu depoimento. Especificamente, o presidente discutia aquilo que chamou como "a pertinência do depoimento" ou também "o alcance testemunhal" do mesmo. Luis argumentava da sua importância para sustentar a tese, colocada por eles no início do julgamento, no sentido de não se tratar de um "caso excepcional", "uma desgraça acidental", mas afirmar a existência de práticas institucionais que dão suporte a intervenções como aquelas aí julgadas. O presidente respondia que meu depoimento "não aportaria em nada ao objeto do processo", porque justamente não falaria sobre "os fatos". "Mas, enfim, está aqui, veio do Brasil, vamos ouvir o que tem para dizer", concluiu o presidente e pela primeira vez se dirigiu a mim, que assistia à situação sem saber se teria que ir embora da sala ou se efetivamente iria depor.

esta reflexão se refira mais ao processo escrito (prazos, férias, rotinas burocrática), no caso do rito do "juicio oral", é importante para entender o transcorrer relativo do tempo da audiência para seus distintos participantes, enquanto a administração do "tempo judicial" aparece como um recurso distribuído (e percebido, acrescentaria eu) de forma desigual (Tiscornia, 2006, p. 139).

Horizontes Antropológicos, Porto Alegre, ano 18, n. 38, p. 313-339, jul./dez. 2012 
Presidente: Boa tarde, seu nome completo, por favor.

Eu: Lucía Eilbaum.

Presidente: Apenas como formalidade, porque no seu caso não seria nem necessário, lhe pergunto: foi lido o artigo que penaliza o falso testemunho?

Eu: Sim.

Presidente: Só como formalidade, vou lhe tomar o juramento: jura ou promete dizer a verdade de tudo quanto saiba ou lhe fora perguntado?

Eu: Sim, juro.

A ênfase na frase "apenas como formalidade" evidenciava a excepcionalidade do tribunal em me ouvir e, de forma mais geral, em ouvir testemunhos que não falassem pontualmente sobre as circunstâncias dos fatos, "o objeto do processo", mas sobre os mesmos desde um ponto de vista mais contextual. Naquele juicio eu voltaria a ouvir a frase "o objeto do processo". Foi em relação ao depoimento da mãe de Dario. Diante da "desistência" por parte da mesma, o presidente expressou: "Pois é, de qualquer forma não iria depor nada em relação ao objeto do processo.” A mãe não tinha presenciado nenhum dos "fatos" julgados; iria depor sobre a perda de seu filho e as dificuldades que isso trouxe para ela e a família.

Voltando ao primeiro dia, após aquele breve interrogatório e meu juramento, o presidente deu a palavra para Luis Real, para ele começar o "interrogatório". Luis apenas me deu pé para eu começar a falar, sem focalizar em uma pergunta específica. Indicou para eu dizer minha profissão, onde trabalhava e para comentar sobre minha pesquisa vinculada ao assunto em questão. Minutos antes, enquanto o presidente conversava com Luis, rapidamente pensei que, caso aceitassem meu depoimento, deveria ser breve e objetiva. Muitas testemunhas do "objeto do processo" tinham sido "desistidas", a audiência já levava mais de sete horas, e ninguém parecia estar muito disposto a ouvir longas argumentações antropológicas. Em frases curtas e diretas, tentei repetir o argumento que, mentalmente, tinha repetido uma e outra vez, durante a espera, na sala das testemunhas.

Referi-me às pesquisas desenvolvidas, desde o ano 1997, no âmbito do Equipo de Antropología Política y Jurídica da Universidade de Buenos Aires, sobre as práticas e rotinas próprias de um "fazer policial", e sobre casos de "violência institucional". Achei pertinente referir algumas características da 
perspectiva antropológica e de seu método etnográfico. Acho que fazia essa referência para, eventualmente, justificar minhas afirmações. Por isso, mencionei o caráter local, não generalizável, das pesquisas antropológicas; o interesse pela dimensão social, e não pelos indivíduos identificados por seus nomes e a ênfase na análise qualitativa dos dados empíricos. Estendi-me mais um pouco sobre o que chamei de "resultados" da pesquisa, em função da identificação, em diversos casos de "violência policial", de padrões referidos a práticas e rotinas institucionais. Falei do "apriete" e "quiebre" como técnicas de investigação, dentro de uma tradição investigativa que prioriza, antes que a produção de provas "técnicas" - perícias, testes de DNA, inspeções oculares, busca de digitais -, a obtenção de provas através de testemunhos orais e, dentro destas, a obtenção da confissão como garantia de "verdade" (Bovino, 1995; Eilbaum, 2008; Tiscornia, 1998; Renoldi, 2008). ${ }^{7}$ Falei também sobre as relações hierárquicas e as formas de socialização em uma ética própria que o antropólogo brasileiro Roberto Kant de Lima tem chamado de "ética policial". ${ }^{8}$ Enfatizei com essa categoria a existência de normas e códigos de conduta cujos valores têm uma referência corporativa e não necessariamente legal. Respeitar aqueles valores, e não os referidos à lei, pode ser legitimado como "o correto", "o natural", aquilo que os policiais aprendem e são socializados a fazer. Sabia que com essas palavras eu poderia dar lugar a perguntas dos advogados, em especial, daqueles que defendiam os policiais de menor hierarquia.

Quando dei por terminada minha fala, o presidente consultou se as partes gostariam de fazer alguma pergunta. Os únicos dois advogados que formularam perguntas eram os mesmos que tinham intervindo em relação ao meu depoimento no início da audiência. Soube que naquele começo de dia tinha ocorrido outro entrevero sobre meu depoimento. Foi quando Luis solicitou que eu depusesse naquele primeiro dia, antecipando minha intervenção.

6 “Apertar" alguém é pressioná-lo física ou psiquicamente para extrair dele certas informações. "Quebrálo" é ter sucesso nessa tentativa, quer dizer, conseguir que o sujeito se dobre diante das pressões e ameaças e, assim, forneça a informação procurada.

7 A busca da confissão enquanto "rainha das provas", como parte de uma tradição inquisitorial de produção de verdade, tem sido assinalada, para o caso do Brasil, por Lima (1999, 2007) e Kant de Lima (1995, 1989). No caso da França, ver Garapon (1999). Ver também Berman (1996).

8 Na sua etnografia da Polícia Civil do estado do Rio de Janeiro, Kant de Lima (1995, p. 65) identifica a "ética policial" como sendo um conjunto especial de regras e práticas que serve como fundamento para o exercício de uma interpretação autônoma da lei e que, como tal, imprime à aplicação da lei uma característica particular, própria das práticas policiais.

Horizontes Antropológicos, Porto Alegre, ano 18, n. 38, p. 313-339, jul./dez. 2012 
Argumentou, por um lado, que "tinha viajado desde o Brasil" e, por outro, que pela natureza da minha pesquisa era necessário eu poder observar os outros dias do juicio. O advogado de Gómez objetou "se a antropóloga poderia ter posteriormente acesso assegurado na sala", mas ninguém pareceu se incomodar em demasia. O advogado defensor de Sánchez até afirmou que "o depoimento da antropóloga pode ser de interesse da causa".

No decorrer do meu depoimento, a pergunta do advogado de Sánchez, motorista na viatura, não demorou a aparecer. Citou um conhecido livro no âmbito do ensino da antropologia, ${ }^{9}$ fazendo referência ao "estudo do microclima" de um determinado ambiente, ressaltando em tal colocação se eu tinha estudado as relações hierárquicas dentro de uma comisaría. O advogado de Gómez também fez uma pergunta. Era aquele questionamento que eu esperava que fosse feito: com quantos casos eu tinha trabalhado para afirmar aquilo que afirmava? Com minha resposta, deu-se por terminada minha intervenção. Fui retirada da sala e acompanhada até a saída do prédio por um funcionário do tribunal. Achei que fosse funcionário judicial.

Funcionário: Muito bom seu trabalho, gostei muito, o problema é se confrontar contra a instituição como um todo.

Eu: Claro, eu apenas quis ressaltar alguns aspectos de meu trabalho vinculados ao caso.

Funcionário: Eu quero sair disto aqui, acho horrível, por isso estou no segundo ano do curso de direito.

Eu: Você trabalha no tribunal?

Funcionário: Sim, mas eu sou policial. E eu sei o que é a polícia, é como você disse. Eu tive a enorme sorte da minha mãe ser loira de olhos claros e eu ter puxado a ela e não a meu pai. Digo isso porque, quando jovem, morava do lado da favela e eu sei que se fosse preto como meu pai a polícia me pararia o tempo todo, como fazia com meus amigos. A discriminação é muito forte - disse enquanto abria a porta do prédio já fechada com chave.

Eu: Pois é. Bom, eu volto amanhã para assistir a audiência. Até amanhã.

Funcionário: Tchau, um prazer conhecê-la.

9 El salvaje metropolitano, de Rosana Guber (1991). 
Novamente senti nessa rápida conversa a excepcionalidade de meu depoimento. Por um lado, o funcionário marcava a dificuldade de circunscrever o mesmo dentro da "lógica judicial", ressaltando que minha perspectiva não permitia a individualização e singularização das condutas denunciadas. Uma coisa era "denunciar" - tal como ele parecia ter percebido meu depoimento - "a instituição como um todo"; outra coisa era fazer as críticas em função de condutas e pessoas concretas. Por outro lado, a minha intervenção tinha provocado nele uma espécie de desabafo sobre sua situação profissional e pessoal. Assim, embora estivesse fora da lógica jurídica de atribuir condutas a indivíduos concretos, minha fala, justamente por ser genérica e anônima, parecia ter atingido, senão "outros" policiais, ao menos aquele.

Ao mesmo tempo, depor, sob juramento, diante do tribunal, dos seis imputados, dos seus advogados, após mais de sete horas de espera sem comer nem beber, me fez pensar em como se sentiria uma testemunha cujo depoimento poderia ser questionado por alguma das partes. Eu já tinha observado depoimentos onde uma testemunha era perguntada e reperguntada, recalcada pelo fato de estar sob juramento, assinalada nas suas contradições, e até advertida pelo tribunal. Sempre percebia nervosismo e inquietação nelas. Mas nunca tinha pensado no que poderiam significar as longas horas de espera, em condições incômodas e, eventualmente, em uma mesma sala com outras testemunhas com posições contrárias à própria. Um depoimento podia ter consequências importantes na vida cotidiana das pessoas. A experiência de depor, e de me expor, me permitiu ter acesso a essas outras dimensões do ato de um depoimento judicial. Comecei a pensar, assim, que essas experiências vividas pelas pessoas que intervêm como testemunhas devem ir constituindo um saber e um fazer próprios do ambiente judicial que permitam se mover nele. Apesar dessas reflexões iniciais, nos primeiros momentos, após minha intervenção, uma forte sensação de incômodo predominou em mim.

\section{0 "incômodo" da antropóloga}

A conversa com o funcionário policial do tribunal foi a primeira repercussão que tive do depoimento, após uma sensação bem estranha de ter me exposto demais. Explico-me: até o momento só tinha assistido a juicios como observadora, na qualidade de "público". Nessas ocasiões era questionada 
sobre meu interesse em estar aí pelos familiares presentes, seja do acusado ou da vítima. Ao não me reconhecer como alguém envolvida direta ou indiretamente no processo, percebia uma vontade de enquadrar minha presença em alguma posição. Identificando meu interesse em estudar e pesquisar sobre o Judiciário, sempre fui bem recebida por essas pessoas, inclusive tendo a possibilidade de conversar com elas durante os longos intervalos. Passar para "o outro lado", sair da posição de observadora, naquela ocasião tinha sido uma mudança importante. Após a tensão e o cansaço, comecei a perceber as vantagens de tais mudanças em relação à minha pesquisa. Mas, logo depois do depoimento, a sensação de incômodo prevaleceu. O que era esse incômodo? Ou melhor, o que ele podia significar?

Acredito que tal incômodo estivesse no encontro entre três visões da realidade próprias de saberes distintos: o antropológico, o jurídico e o judicial. $\mathrm{Na}$ atitude dos juízes e nas perguntas dos advogados, parecia se buscar um conhecimento que não aquele que a antropologia, pelo menos do meu ponto de vista, poderia aportar. E o conhecimento que ela poderia trazer não parecia "servir" para eles. As linguagens eram diferentes, mas, mais do que isso, eram distintas as perspectivas. Quando uma testemunha depunha nos tribunais, a linguagem dela não correspondia, geralmente, à linguagem jurídica. Também não se esperava isso dela. Contudo, o objeto e a finalidade de sua fala estavam dentro dos padrões do saber judicial: aportar dados concretos e individualizados sobre o "fato" julgado. O que ela aportasse serviria, ou não, para determinar a responsabilidade individual da(s) pessoa(s) julgada(s). Com seus próprios termos e desde seu ponto de vista, a testemunha falava na perspectiva judicial. $\mathrm{Eu}$, como antropóloga, não só não falava a linguagem jurídica, mas também não falava a judicial. Quer dizer, não falava da perspectiva que, conforme o critério de investigação e julgamento comum a esse campo, seria "útil" para aquilo que aquelas pessoas estavam fazendo naquele momento: disputar e definir a culpabilidade individual dos "acusados".

Quando o advogado de Sánchez apelou ao livro de metodologia em antropologia, pensei que poderia haver um encontro - talvez inesperado de interesses. No entanto, a pergunta dele ia dirigida a sustentar a defesa de Sánchez no princípio da "obediência devida". Quando eu falava do fato de certas práticas responderem a uma socialização institucional referia-me a processos de longa duração nos quais os agentes, reflexivamente e cada um desde sua posição, priorizam e respondem a valores próprios de uma "ética policial".

Horizontes Antropológicos, Porto Alegre, ano 18, n. 38, p. 313-339, jul./dez. 2012 
Em tal caso, se ele assemelhava a instituição a um exército, onde as regras formais são obedecidas hierarquicamente, eu queria enfatizar que regras formais e informais são aplicadas de acordo com valores próprios que não as regras escritas.

Quando o advogado de Gómez me perguntou pela quantidade de casos sobre os quais sustentava minhas observações, percebi que pouco tinha a ver com os critérios de legitimação do conhecimento antropológico. Comecei respondendo que a metodologia antropológica não sustenta suas pesquisas em análises quantitativas, mas qualitativas de acordo às regras do método etnográfico. Interrompeu-me: “OK, mas quantos casos?” Tentei lembrar do número e dei uma cifra aproximada, também baseada nas pesquisas de colegas. Por último, acrescentei que havia organismos civis com bases de dados quantitativos sobre casos de "violência policial", como o Centro de Estudios Legales y Sociales. "Ah, o CELS", disse com um tom desqualificador. Ao repetir "o CELS", percebi que o advogado me enquadrava na perspectiva jurídica e política que aquele organismo representava para ele, isto é, a perspectiva de uma associação defensora dos direitos humanos, dedicada ao trabalho com denúncias de casos de "violência policial". Essa era a perspectiva que ele pareceu priorizar ao ouvir meu depoimento, e não aquela do saber antropológico. Pouco lhe importava também o fato de efetivamente eu ter a ver ou não com aquela organização.

Ao mesmo tempo, ao insistir sobre a quantidade de casos sobre os quais eu estaria sustentando meus argumentos não só desqualificava as informações por mim aportadas, mas também refletia uma perspectiva conforme a qual as mesmas só poderiam ser consideradas como "científicas" se sua base fosse quantitativa. Essa parecia ser a ideia de "rigor científico" que o saber jurídico poderia aceitar no seu campo como forma de validação de argumentos não jurídicos; uma ideia bastante expandida - diga-se de passagem - no senso comum como padrão do que seja "ciência".

Com essas ideias, não quero dizer que um depoimento feito desde um ponto de vista antropológico não pudesse ser utilizado pelo saber jurídico e/ ou judicial. De fato existem casos em que tal ponto de vista tem tido sucesso em se instalar como um conhecimento válido. Em um caso de "abuso policial" de alta repercussão nacional, o caso referido à morte do jovem Walter Bulacio, a antropóloga Sofia Tiscornia participou como "perito antropóloga" na audiência realizada diante da Corte Interamericana de Direitos Humanos (CIDH). 
Sua intervenção foi solicitada pela parte que representava a família Bulacio, em demanda contra o Estado argentino. As características específicas do procedimento correspondente àquela corte internacional diferenciam, a meu ver, o possível alcance de um depoimento de caráter antropológico no âmbito de um juicio penal, tal como o aqui relatado.

Em primeiro lugar, são violações dos direitos humanos nas quais o Estado é o responsável. Trata-se por isso de um tipo particular de crime e, portanto, não pode ser tratado com as mesmas regras que nos tribunais locais [...]. Se a Comissão aceita o caso [...], inicia-se um processo cuja lógica não é penal porque as partes não se enfrentam em um jogo em que um perderá e o outro não. [...] O que os peticionários perseguem não é só a condenação do Estado em um caso particular, mas aspiram que seja construído, a partir do caso, um precedente, e, além disso, que sejam estabelecidas políticas, que sejam reformuladas práticas habituais, que seja legislado de acordo com os princípios dos direitos humanos. (Tiscornia, 2005, p. 59, grifo da autora, tradução minha). ${ }^{10}$

Se as aspirações dos peticionários se assemelham às expectativas de Luis Real ao me convidar a participar como "especialista", tal como foi argumentado no juicio, os objetivos do tribunal e do julgamento penal na província de Buenos Aires não pareciam dar lugar a tais pretensões. Não era o Estado quem estava sendo responsabilizado, nem sequer uma agência do mesmo, mas indivíduos de carne e osso que, nesse caso, eram suspeitos de ter cometido um crime no exercício de suas funções públicas. A eventual condenação não iria recair no Estado, mas nesses indivíduos. $\mathrm{E}$ a tal condenação não era prevista para reformular práticas ou formular políticas, mas para estabelecer penas individuais e quantificáveis em períodos de tempo. Aquilo que estava em jogo, para os atores, em um juicio penal, como o aqui apresentado, era principalmente a individualização das informações produzidas: quem, quando e como fez o que a quem. Era um saber fundamentalmente instrumental, que buscava soluções para certas situações - sejam os "crimes", seja a "defesa" de seus supostos autores. Em contraste, o saber antropológico, e nesse contexto meu

${ }^{10}$ No Brasil, a antropologia também é requerida para a realização de laudos a serem apresentados em litígios judiciais. No entanto, também não se trata de conflitos na área criminal. Eles têm sido solicitados em questões como "delimitação e identificação de terras indígenas" e "terras quilombolas", "impacto socioambiental" e "patrimônio histórico paisagístico e etnográfico" (ver http://www.abant.org.br).

Horizontes Antropológicos, Porto Alegre, ano 18, n. 38, p. 313-339, jul./dez. 2012 
depoimento, não buscava solução alguma, mas problematizar certas práticas. Não podendo ser instrumentalizado, não parecia "útil” para aqueles ouvintes.

Assim, naquele julgamento, o que meu incômodo parecia indicar era um choque de legitimidades disciplinares. Minha perspectiva não parecia encaixar onde o saber jurídico e o saber judicial tinham prioridade sobre qualquer outro tipo de linguagem, impondo seus objetivos, formas de construção dos "fatos" e técnicas de relato dos mesmos. No mesmo sentido, os atores judiciários também não pareciam sensíveis à incorporação de novas perspectivas. $\mathrm{O}$ incômodo parecia se basear, então, no fato de eu submeter um saber, para mim familiar, em um ambiente ao qual the era estranho.

\section{A autoridade dos argumentos}

Nas audiências posteriores ao primeiro dia do juicio, o papel confortável da observação etnográfica me permitiu relevar muitas informações úteis para posterior análise. Contudo, a experiência de depor e me investir do papel de "testemunha" por um dia significou também um aprofundamento nas amplas possibilidades de percepção do fazer etnográfico. O incômodo próprio desse momento transformou-se depois em parte das reflexões aqui apresentadas, dando outra visão sobre minhas observações de juicios. Uma delas relativa ao tipo de informação e de linguagem com que os participantes do juicio - profissionais e leigos - faziam suas atuações.

À exceção de mim, todas as outras testemunhas estavam lá para prestar seu depoimento, nos termos do presidente do tribunal, sobre o "objeto do processo". Assim, as perguntas realizadas eram sobre informações pontuais. Cada testemunha, a partir da posição que tinha ocupado naquele dia, poderia responder o que tinha visto e/ou ouvido. Como observado em outros juicios, a forma de expressão das testemunhas não respondia a uma linguagem jurídica. Ela podia responder à linguagem comum, cotidiana, ou bem a uma linguagem técnica própria da profissão ou ofício de quem estivesse depondo. Nesse caso, isso aconteceu em relação ao fato de a maioria das testemunhas serem policiais (em outros, a linguagem técnica se referia a médicos, psicólogos, técnicos em criminalística, ou outras especialidades de peritos). Assim, os policiais utilizaram nos seus relatos jargão próprio da polícia - algemas como "ganchos", por exemplo. 
De todo modo, eles eram ouvidos e indagados pelas "partes" e pelos juízes, ficando claro que seus depoimentos estavam dentro da rotina esperada para esse ritual judiciário. Da mesma forma, as testemunhas civis expressavam-se em seus próprios termos e formas. Em nenhum dos casos, a forma e a linguagem jurídicas eram exigidas para legitimar as intervenções orais. Esperava-se que aquilo que essas testemunhas tivessem para aportar fosse informado a partir de um saber leigo - do ponto de vista do saber jurídico -, pois esse era seu papel nas audiências. A sua legitimidade estava em elas serem testemunhas dos "fatos" e não na sua autoridade ou expertise jurídica.

Ora, nos depoimentos dos policiais, chamou minha atenção o fato de, dentre as perguntas sobre informações pontuais, também surgirem perguntas referidas a rotinas policiais. Assim, as práticas mencionadas no meu depoimento como rotinas próprias de uma ética policial particular também apareciam na boca de chefes e funcionários da instituição. O "apriete", a "parada de livros", o "perro" 11 foram mencionados, com mais ou menos naturalidade, nos depoimentos daqueles policiais-testemunhas mais experientes na instituição. Essas referências a práticas "não legais, mas usuais", como depôs um alto chefe da instituição, pareciam mostrar que não só os acusados estavam sendo julgados, mas, pelo menos, que as testemunhas se moviam em um terreno em que seus ditos podiam comprometer também a instituição policial. Se o juicio fosse tomar um sentido ou outro seria decisão final dos três juízes, que não pareciam muito dispostos a saírem do seu papel.

Isso me pareceu notável na forma com que meu depoimento foi recebido em relação ao depoimento dos policiais. Ambos falavam sobre o fazer policial e as práticas rotineiras da instituição. No entanto, a autoridade dos argumentos parecia estar legitimada na boca dos policiais enquanto atores diretos, ou bem especializados em segurança pública, e não através do saber antropológico. Este último não parecia encontrar ressonância nas autoridades judiciais. A fala dos policiais, embora se afastasse por momentos do "objeto do processo", marcando comportamentos cotidianos, era ouvida e indagada com o mesmo rigor e interesse que as informações sobre os "fatos" que eles pudessem aportar. "Apriete", "quiebre", "parada de livros" eram mencionadas por eles

11 "Perro", que em espanhol significa cachorro, é a categoria policial utilizada para denominar uma arma que é colocada posteriormente na cena do crime.

Horizontes Antropológicos, Porto Alegre, ano 18, n. 38, p. 313-339, jul./dez. 2012 
como "conceitos de experiência próxima" (Geertz, 2002a, p. 87), mostrando familiaridade, domínio profissional e de primeira mão - poderíamos até dizer "testemunhal" - sobre aquelas práticas. Diferentemente, quando eu me referia a elas o fazia apelando a "conceitos de experiência distante", mediados por um saber considerado nesse âmbito como "não científico". Nesse sentido, meu depoimento sobre as práticas policiais, baseado nas pesquisas empíricas, diferente daqueles dos policiais, era aceito "só por formalidade". Percebi nessa distinção que não eram necessariamente os argumentos que eram questionados, mas a autoridade de quem os pronunciasse, ou melhor, do saber que os fundamentasse. ${ }^{12}$

\section{Os "profissionais"}

O momento indicado para os profissionais se expressarem no juicio era no início e no final da audiência. No início, para apresentar as respectivas linhas de acusação ou de defesa; no final, para expor as alegações, interpretando os "fatos" e o papel neles dos respectivos acusados/defendidos. Durante o andamento da audiência, as intervenções limitavam-se em geral à formulação de perguntas, ou solicitações pontuais diante do tribunal. Foi no final do juicio que percebi nas intervenções dos "profissionais" do ritual judicial, com maior clareza, a combinação de duas linguagens com diferentes sentidos de legitimidade.

Após quatro dias de audiências, aquela destinada às alegações finais de cada uma das "partes" durou aproximadamente seis horas. O primeiro a expor sua alegação foi o promotor. Ele relatou sua versão dos "fatos" e descreveu "a criação da trama lamentável pela qual se adulteraram provas [...], os acusados se distribuíram funções e entre todos deram uma versão dos fatos com o objetivo de encobrir e mascarar o acontecido diante da Justiça". Deu por provada a morte de Dario, a partir das pericias médicas e do depoimento dos médicos no debate. Qualificou penalmente esses fatos, atribuindo um tipo penal e uma pena a cada acusado e citando as provas testemunhais que creditavam a "autoria e participação" de cada um deles. Objetiva e direcionada à

12 Kant de Lima (2011, p. 43) tem chamado a atenção para uma distinção entre a "autoridade dos argumentos" e a "os argumentos de autoridade" para contrastar uma lógica baseada na argumentação e no consenso de uma baseada no dissenso e na imposição de uma autoridade externa ao conflito. 
solicitação das penas, a fala do promotor não foi interrompida em momento nenhum pelo tribunal.

Em seguida, a palavra foi dada a Luis Real, como representante da família de Dario. Afirmou aderir em parte à alegação do promotor, sendo que apresentaria um "fato" com algumas nuanças diversas. Luis se deteve no tempo em que foi prolongada a detenção de Dario na viatura, com o objetivo de "infringir dor, física e psíquica, e de gerar não lugares, nos quais não existe registro e a legalidade é colocada entre parênteses, como mencionou a antropóloga Eilbaum aqui ouvida pelas partes". Foi com esta frase a única instância em que meu depoimento "especializado" era retomado por algumas das "partes". Seguindo essa linha, Luis começou a argumentar em torno do teor repressivo das políticas públicas de segurança da província e das características das formas inquisitivas de investigação. No entanto, foi rapidamente interrompido pelo presidente, avisando que seu tempo estava por se esgotar. Concluiu retomando a argumentação jurídica e solicitando as penas que considerava pertinentes.

Ao passar a palavra para os defensores, o presidente disse "estimular, como o tem feito durante todo o juicio, o princípio de adesão entre os defensores". Referia-se à possibilidade de aglutinar argumentos em um mesmo sentido e não se repetir uns aos outros. Confirmava o presidente uma atitude presente desde o primeiro dia de audiência, de acelerar o processo e economizar palavras e argumentos. Seja "estimulando a desistência" de testemunhas, seja solicitando a adesão de argumentos entre os defensores, o "tempo" do tribunal parecia se mostrar um bem escasso. ${ }^{13}$

Cada um dos defensores fez sua alegação em prol de seus respectivos defendidos. Os argumentos foram jurídicos... à exceção do advogado de Sánchez. Ele começou seu discurso com argumentos sobre a vida estigmatizada dos jovens nascidos em bairros populares, concluindo que "Dario não foi uma vítima policial, mas vítima de uma sociedade que não se ocupou dele nem de sua família. Essa é uma verdade que dói." Prosseguiu argumentando sobre a estrutura hierárquica e militarizada da polícia, para, finalmente, sustentar a tese de "obediência devida" de seu defendido. Foi o momento que recebeu a

13 Novamente, Garapon (1999, p. 62) faz referência ao tempo do ritual judiciário como dotado de um valor superior, cujo controle fica em poder do presidente. 
reprimenda do juiz, para "se limitar ao objeto de conhecimento deste processo e de seu defendido, pois não é este um fórum adequado de índole doutrinária”. $\mathrm{O}$ advogado retomou rapidamente a argumentação jurídica.

$\mathrm{O}$ presidente deu lugar às réplicas, solicitando que fossem "sintéticas, objetivas e breves". Cinco dias depois foi realizada a audiência para leitura da sentença. O presidente anunciou que a secretária leria "a parte resolutiva da sentença, porque os fundamentos têm mais de cem páginas". Resapo foi condenado à pena de prisão perpétua, Gómez a cinco anos de prisão efetiva, ${ }^{14}$ o comisario e Sánchez a três anos de prisão condicional e serviços comunitários, e o oficial de serviço e o subcomisario foram absolvidos. Aos poucos, fomos sendo retirados da sala. A audiência tinha acabado.

\section{Os saberes em jogo}

Minha participação como antropóloga no juicio de Dario me confrontou com uma linha de reflexão que até o momento vinha pensando restritamente em função do convívio profissional com pessoas formadas em direito. Há vários anos que meu trabalho de pesquisa está vinculado à área da antropologia do direito e, em tal sentido, tenho interagido e trabalhado junto com advogados e funcionários do Judiciário. A partir dessa experiência, tenho refletido sobre as visões de mundo diferenciadas próprias do saber antropológico e do jurídico. Na época, percebia em meus colegas formados em direito uma forma rígida, coerente e autojustificada de ver o mundo e de opinar sobre a própria prática, enfatizando geralmente como as coisas deviam ser. Nesse sentido, essas certezas jurídicas costumavam se confrontar com minhas relativizações ou questionamentos sobre por que as coisas eram de tal modo (Eilbaum, 2008). Em uma linha semelhante, Kant de Lima e Lupetti (2010) discutem a dificuldade que o campo jurídico tem de aceitar a "intervenção" de outros saberes em seu próprio universo. Dentre outros motivos, eles apontam para o fato do "fazer antropológico pressupor a relativização de verdades consagradas enquanto o fazer jurídico através delas se reproduzir, sendo este contraste metodológico um significativo obstáculo ao diálogo destes campos" (Kant de Lima; Lupetti, 2010, grifo dos autores).

${ }^{14}$ Naquele dia, Gómez não se apresentou na audiência e até hoje está foragido. 
A partir dessas considerações, na época, em minhas reflexões, eu ressaltava o contraste entre o saber antropológico e o jurídico. A intervenção direta e pessoal no espaço de um ritual judicial, saindo do papel da observação etnográfica, me permitiu pensar em um terceiro saber, próprio dos espaços de atuação do Judiciário, que chamo aqui de "saber judicial". Nesse sentido, percebi que o saber antropológico se diferenciava tanto do saber jurídico quanto deste último.

A experiência de depor me confrontou com o desafio de expor, explicar e explicitar as bases e fundamentos do saber antropológico, diante de pessoas com interesses pontuais e prontas para questionamentos e indagações. A "lógica do contraditório" (Kant de Lima, 20115) estava aí disponível para refutar ou cooptar meu depoimento como sendo a favor ou contra certos interesses. Enquanto o advogado de Sánchez buscava apoio nos meus argumentos, o advogado de Gómez tentava claramente refutar a legitimidade da minha posição e do saber - "qualitativo" - da antropologia, porque assim era melhor - legítimo - para os interesses de seus respectivos "clientes". Tratava-se, nesse sentido, de um uso instrumental da minha fala, mas que não necessariamente legitimava o saber antropológico no âmbito judicial. Sob essa lógica, eu me encontrava, nesse espaço, fora da "forma" da exposição acadêmica, onde, a partir da exposição das reflexões sobre pesquisas empíricas, podem ser construídos consensos provisórios sobre certos temas (Kant de Lima; Lupetti, 2010 ${ }^{16}$ ).

Assim, senti-me na necessidade de legitimar as bases do saber etnográfico diante de outros saberes. Entre aquilo que eu falava e aquilo que os advogados e juízes estavam dispostos a aceitar não havia pressupostos comuns. Toda a argumentação devia ser explicitada, demonstrando a pertinência e competência das pesquisas antropológicas. "Etnografia", "métodos qualitativos",

\footnotetext{
15 Segundo Kant de Lima (2011, p. 29), a lógica do contraditório se "explicita pela promoção de um dissenso infinito, o qual só se interrompe através de uma autoridade externa às partes, que lhe dá fim e declara uma tese vencedora e a outra, vencida".

${ }^{16}$ Os autores sugerem como característica da construção de conhecimento jurídico a dificuldade de construir consensos: "Neste processo, em busca de UMA verdade, dá-se mais relevância, para descobri-la, à lógica dos argumentos de autoridade do que àquela da autoridade dos argumentos, esta última própria da argumentação científica contemporânea, fundada na construção sucessiva de consensos temporários, fundamento de seu suporte fático." (Kant de Lima; Lupetti, 2010, grifo dos autores).
}

Horizontes Antropológicos, Porto Alegre, ano 18, n. 38, p. 313-339, jul./dez. 2012 
“observação participante”, "práticas sistemáticas”, "rotinas burocráticas”, "ética policial", entre outras, eram categorias que deviam ser acompanhadas de uma explicação que desse um sentido - e não outro - ao seu uso.

Para além disso, a recepção do meu depoimento por parte dos interlocutores no juicio mostrou, por um lado, que minha presença era aceita apenas "por formalidade", pois eu "já estava aí". Nem o juramento de dizer a verdade, nem o registro de meus dados pessoais pareciam, no meu caso, fazer parte das exigências legais comuns às outras testemunhas. Decisão que, de alguma forma, me colocava em uma posição, senão fora, pelo menos liminar do ritual. Por outro lado, meus argumentos também eram recebidos de forma a deixar clara a excepcionalidade da minha intervenção. Os juízes não formularam pergunta alguma. Apenas dois advogados fizeram perguntas, em notável contraste com os interrogatórios de outras testemunhas.

Pareceu-me que a falta de informações pontuais e individualizadas que eu pudesse aportar sobre os "fatos" tirava o interesse acerca do meu depoimento, pois, ao final, o saber judicial tem como finalidade atribuir autorias individuais para fatos também individualizados (Misse, 1999). Nesse contexto, por momentos, me parecia que o discurso de Luis também parecia esbarrar com um descompasso, senão de linguagem, pelo menos de perspectiva. O objetivo que o levou a me propor como testemunha - demonstrar que não se tratou apenas do "erro" de um policial, mas que a responsabilidade do acontecido respondia a formas institucionais de intervenção policial - se refletia em outras de suas intervenções (apontar uma tradição inquisitorial, sugerir o papel pouco importante dado à vítima no processo), sistematicamente interrompidas pelo presidente do tribunal. Tais interrupções, insistindo com o tempo limitado da fala, apontavam também a centrar o discurso do Luis em um sentido em que apenas pareciam ter lugar argumentações jurídicas.

Estas, próprias do saber jurídico, estavam legitimadas na boca dos profissionais do ritual: juízes, promotor, advogados. Esperava-se e se estimulava que esses atores proferissem seus discursos na linguagem jurídica, se apropriando da terminologia normativa e doutrinária. Era esse saber jurídico que poderia ser caracterizado como produto do conhecimento especializado dos agentes jurídicos e profissionais, resultado da aplicação de regras de procedimento, normas penais e doutrinas jurídicas acerca dessas normas, aprendidas em processos de educação formal, em particular nas faculdades de direito, que tinha legitimidade e tempo para ser explanado. 
Isso não quer dizer que o saber jurídico fosse o único ou o mais presente no desenvolvimento da audiência. Diferentemente do saber antropológico, que não parecia ter cabimento nesse espaço, a interação e o diálogo entre as testemunhas e os profissionais apresentava um saber diferenciado, "adequado" à audiência. Ele respeitava os ritmos, tempos e objetivos do juicio, embora não fosse necessariamente técnico nem dogmático. Era um saber judicial, que, apesar de ter uma linguagem diferente da jurídica, encontrava legitimidade naquele espaço.

E esse saber judicial, embora atrelado ao saber jurídico, toda vez que seu contexto de atuação exigia o respeito a regras de procedimento e normas legais, não se esgotava nele. Contudo, me interessa ressaltar que não se tratava de um contraste entre leigos e profissionais ou especialistas, pois estes últimos também se utilizavam desse saber, seja nas interações com os leigos, seja em outros momentos da audiência para fazer valer suas estratégias jurídicas, ou processuais. Assim, enquanto o saber jurídico permitia a tradução e encaixamento daquilo que acontecia nos termos jurídicos (vocabulário, tempo e forma), o saber judicial conduzia a audiência e as interações entre os envolvidos. E, por sua parte, o saber antropológico, pelo menos nesse tipo de juicio, onde se julgava instrumentalmente autores individuais por fatos individualizados, parecia não achar um interesse comum com esses dois saberes, capaz de promover o diálogo e o aproveitamento de perspectivas distintas.

Seguindo o aqui sugerido, podemos pensar que cada saber estabelecia uma relação distinta entre "fatos" e "leis" (Geertz, 2002b). O saber jurídico privilegiava a lei e buscava, dessa forma, que os fatos fossem narrados em conformidade com a positividade da norma. O saber antropológico privilegiava os fatos e neles encontrava a tradução da norma, mas sendo aquilo que é e não aquilo que deve ser. Por último, o saber judicial, de alguma forma, parecia buscar a cada instante uma oportunidade para jogar com a dicotomia fato-lei, de acordo com os interesses do profissional que esgrimisse os argumentos - seja defesa, seja acusação. Em outras palavras, fatos e leis pareciam se aproximar e distanciar a cada momento, a cada intervenção, dependendo dos interesses em jogo.

Ora, se a relação entre fatos e leis variava de um saber a outro, isso se devia ao fato das “"configurações factuais' não serem meros objetos que se encontram espalhados pelo mundo, e que podem ser carregados fisicamente até o tribunal para uma demonstração audiovisual, mas diagramas altamente 
editados da realidade" (Geertz, 2002b, p. 258). Assim, a forma com que cada "parte" representava os "fatos", na cena da audiência, refletia aquilo que podia, de um modo ou outro, ser verossímil aos olhos do direito. Isto é, aos olhos de uma forma específica de imaginar a relação entre fatos e leis. Se nem todas essas formas foram bem sucedidas na sua tentativa de resultarem críveis ou legítimas aos olhos do tribunal foi, em parte, porque elas eram portadoras de saberes diferenciados, nos quais a relação entre fatos e leis podia ser encaixada com sentidos distintos e, portanto, com graus de legitimidade desiguais.

Assim, o incômodo - ou a inadequação- que meu depoimento parece ter provocado no tribunal - nesse contexto, o portador mais acabado do saber jurídico - podia ter a ver com o fato de a minha argumentação distanciar os fatos das normas disponíveis e, assim, não auxiliar na tarefa que lhes cabia de elaborar a decisão final "juntando" fatos com leis. ${ }^{17}$ Já as "partes" pareceram avaliar minha intervenção do ponto de vista de seus interesses particulares. Para isso, sustentadas pelo saber judicial, estavam atentas para tirar proveito das oportunidades possíveis para fazer com que fatos e leis se aproximassem ou se distanciassem, dependendo da situação. Assim, em relação à minha intervenção (mas também a todos os outros depoimentos) alguns permaneceram indiferentes, outros trabalharam para desqualificá-la e outros procuraram utilizar parte dela em favor de sua linha argumentativa. Com essa posição, mostravam, a meu ver, que o saber judicial podia interceder entre o saber antropológico e o jurídico, na busca de "leis" que se adequassem aos "fatos" defendidos, demonstrando que ambas as partes da equação são sempre relativas e nunca universais. Nesse sentido, a noção de "sensibilidade jurídica" proposta por Geertz (2002b) - entendida como a relação que cada sociedade estabelece entre fato e lei - pode ser também episódica e, portanto, manipulada em função de interesses diversos.

17 Essa tarefa reflete o que Geertz (2002b, p. 260) tem identificado como o papel das instituições legais: traduzir a linguagem da imaginação - da norma genérica expressa na fórmula "se então" - para a linguagem da decisão - do caso concreto expresso na fórmula "como portanto". A forma e o sentido com que consiga fazer isso determinará um certo sentido de justiça, mais ou menos crível para uma certa percepção local (Geertz, 2002b, p. 261). 


\section{Referências}

BERMAN, H. La formación de la tradición jurídica de Occidente. México: Fondo de Cultura Económica, 1996.

BOVINO, A. Ingeniería de la verdad. No Hay Derecho, Buenos Aires, año VI, n. 12, p. 13-20, 1995.

EILBAUM, L. Los casos de policía en la Justicia Federal en Buenos Aires: el pez por la boca muere. Buenos Aires: Antropofagia, 2008.

EILBAUM, L. De prácticas de investigación y producción de pruebas. Haciendo y deshaciendo versiones, en la policía de la provincia de Buenos Aires. In: KANT DE LIMA, R.; PIRES, L.; EILBAUM, L. (Org.). Burocracias, direitos e conflitos: pesquisas comparadas em antropologia do direito. Rio de Janeiro: Garamond, 2011. p. 147-174.

GARAPON, A. Bem julgar: ensaio sobre o ritual judiciário. Lisboa: Instituto Piaget, 1999.

GEERTZ, C. Do ponto de vista dos nativos: a natureza do entendimento antropológico. In: GEERTZ, C. O saber local: novos ensaios em antropologia interpretativa. Petrópolis: Vozes, 2002a. p. 85-107.

GEERTZ, C. O saber local: fatos e leis em uma perspectiva comparativa. In: GEERTZ, C. O saber local: novos ensaios em antropologia interpretativa. Petrópolis: Vozes, 2002b. p. 249-356.

GUBER, R. El salvaje metropolitano: reconstrucción del conocimiento social en el trabajo de campo. Buenos Aires: Legasa, 1991.

GUBILEI, E. Rutinas policiales: entre la represión del delito y la administración de ilegalismos. Monografia (Graduação em Sociologia)-Facultad de Humanidades y Ciencias de la Educación, Universidad Nacional de La Plata, La Plata, 2009.

KANT DE LIMA, R. A tradição inquisitorial. Revista Brasileira de Ciências Sociais, v. 4, n. 10, p. 65-84, 1989. 
KANT DE LIMA, R. A polícia da cidade do Rio de Janeiro: seus dilemas e paradoxos. Rio de Janeiro: Forense, 1995.

KANT DE LIMA, R. Sensibilidades jurídicas, saber e poder: bases culturais de alguns aspectos do direito brasileiro em uma perspectiva comparada. Anuário Antropológico, v. 2, p. 25-51, 2011.

KANT DE LIMA, R.; LUPETTI, B. O desafio de realizar pesquisa empírica no Direito: uma contribuição antropológica. Paper apresentado no $7^{\circ}$ Encontro da ABCP - Associação Brasileira de Ciência Politica, Recife, 4-7 ago. 2010.

LIMA, L. L. da G. As contraditas no processo inquisitorial. Discursos Sediciosos, Rio de Janeiro, v. 15/16, p. 307-316, 2007.

LIMA, L. L. da G. O tribunal do Santo Ofício da Inquisição: o suspeito é o culpado. Revista de Sociologia e Política, Curitiba, n. 12, p. 17-21, 1999.

MISSE, M. Malandros, marginais e vagabundos: a acumulação social da violência no Rio de Janeiro. Rio de Janeiro: IUPERJ, 1999.

RENOLDI, B. Narcotráfico y justicia en Argentina: la autoridad de lo escrito en el juicio oral. Buenos Aires, Antropofagia, 2008.

TISCORNIA, S. Violencia policial. De las prácticas rutinarias a los hechos extraordinarios. In: IZAGUIRRE, I. (Comp.). Violencia social y derechos humanos. Buenos Aires, Eudeba, 1998. p. 125-146.

TISCORNIA, S. Límites al poder de policía. El activismo del derecho internacional de los derechos humanos y el caso Walter Bulacio ante la Corte Interamericana de Derechos Humanos. In: TISCORNIA, S.; PITA, M. V. (org.). Derechos humanos, tribunales y policias en Argentina y Brasil: estudios de antropología jurídica, Buenos Aires: Antropofagia, 2005. p. 43-69.

TISCORNIA, S. La violencia policial en la Argentina: el caso Walter Bulacio. Tese (Doutorado)-Facultad de Filosofía y Letras, Universidad de Buenos Aires, Buenos Aires, 2006. 